\title{
PARALELLIZMUSOK A ZSOLTÁROK KÖNYVÉBEN
}

\author{
MAGDALÉNA HRBÁCSEK
}

Hrbácsek, Magdaléna: Parallelism in Book of Psalms, 2019, Vol. 1, Issue 2, pp. 31 - 37. DOI: 10.17846/ CEV.2019.01.2.31-37.

ABSTRACT: The poems in the Book of Psalms carry of the peculiarites of the Eastern verse form, therefore of the Hebrew verse: the thought rhythm. Throught the texts of the Psalms, the study presents certain types of thought rhythm and points to the technique of reasoning and deduction of literature of wisdom.

KEYWORDS: Psalms. Hebrew Verse. Thought Parallel. Thought Rhythm.

A Zsoltárok könyve protokanonikus szöveg, és mind a zsidó, mind a keresztény bibliai kánon közös imakincsét képezi. Lírai hangvételén keresztül az ember teljes emocionális palettája hallatszik ki. Olyan érzések és attitüdök fogalmazódnak meg a zsoltárokban, mint például a szenvedés, a betegség, az üldöztetés, a halál, az öröm, a hála, az ujjongás, az Isten utáni vágy, a dicséret, a kérés, valamint a bün- és a szeretetvallomás. A héber Bibliában az Iratokhoz (Ketubim) soroljuk ${ }^{1}$ a bölcsességirodalmi szövegként is kezelt zsoltárokat, mivel olyan életigazságokat is tartalmaznak, melyek az embert a legegyszerübb hétköznapi szituációktól kezdve a bonyolult, egyéni vagy nemzeti kríziseken keresztül a helyes, egyenes útra találásra és járásra tanácsolják. ${ }^{2}$

A héber kánon a babiloni fogság után alakult ki, ezután lett az írás népe a zsidó nép. A zsinagógai liturgikus rend is a fogság után alakult ki, és ebben az időben került be a Zsoltárok könyve is a liturgiába. ${ }^{3} \mathrm{Az}$ addig a nép ajkán élő és továbbhagyományozódó dalok kánoni összeállítása

1 Iratok: Ketubim/Ketuvim: „amik le vannak írva”, a Tanakh harmadik, utolsó része a Tóra (Törvény) és a Neviim (Próféták) után. A Ketubim 11 könyvet tartalmaz, és három csoportba osztható. Az első csoportba a költői könyveket (Szifré emet) soroljuk: a Zsoltárok könyvét, a Példabeszédeket és Jóbot. A második csoportot alkotják az ún. Ünnepi tekercsek, azaz a Hámés Megillót. Ezek a következők: Énekek éneke, Eszter, Rúth, Jeremiás siralmai és a Prédikátorok. A harmadik csoportba soroljuk az egyéb történeti könyveket: Dániel könyve, Ezdrás-Nehémiás könyve, Krónikák könyve.

2 A bölcsességirodalomhoz: (héberül: hákám =»bölcs«, hokmá=»bölcsesség «) szokás sorolni az Ószövetség 5 könyvét: Jób, Zsoltárok könyve, Példabeszédek, Prédikátor, Énekek éneke. A bölcsességirodalom az egész ókori keleten ismert volt. Az óegyiptomi irodalom uralkodó müfaja az ún. sebayit („intelem”, „tanítás”), mely 25 évszázadon át virágzott Egyiptomban. Mintájuk rendszerint ugyanaz: a tanító (apa) a vezetés, államigazgatás szabályait közvetíti „fiának” (a tanítványnak): Ptahhotep intelmei, Merikaréhoz intézett Intelmek Ani Intelmei (18. dinasztia), Ank-Sesonk Intelmei, Insinger-papirusz) A sumér kultúrából nagyszámú bölcs mondás maradt ránk, melyek gyakorlati tanácsokat adnak a világ rendjének megfelelő életfolytatásra (Suruppak Intelmei). A „szenvedő igaz” problematikája - a Jóbtéma - a mezopotámiai irodalomban is megjelenik. Két példa erre $A z$ ember és istene (modern címén a Sumer Jób) és az akkád Ludlul bél némequi („Hadd magasztaljam a bölcsesség urát...”). Izráel sok mindent átvett a környező népek bölcsességirodalmából; és már a családban elkezdődött a bölcsességre tanítás és nevelés. Dávid és Salamon királyok idejében fontos volt a bölcsek, a diplomaták kiképzése. Salamonról olvassuk, hogy híres volt bölcsességéről. Gyakorolta a bírói bölcsességet, a bölcsességet mint a természet ismeretét, a tapasztalatit és teológiait egyben. A királyi udvarban listába szedett ismeretekre utal az 1Kir 5,9 - 14. A bölcsességirodalom hatása a Zsoltárok könyvében is látható (1; 19; 34; 37; 49; 73; 90; 91; 119; 127. és 128. zs.). https://www.arcanum.hu/hu/online-kiadvanyok/ Lexikonok-keresztyen-bibliai-lexikon-C97B2/b-C9942/bolcsessegirodalom-C9A25/.

3 A zsoltárok könyve héberül: Tehilim, Tilim. A zsoltár héberül mizmór, azaz ének zenei kísérettel, latinul psalmos, görögül: psaltér. 
tudatos szerkesztői munka eredménye lehetett, mely a keretes megoldást eredményezte, és az 1. és a 150. zsoltár feszültségében találjuk a 148 (147) zsoltárt. ${ }^{4}$ Számos felosztás ismeretes. Egyrészt tartalmi, másrészt applikatív funkció húzódik a szempontok mögött. A legismertebb az 5 részre való felosztás, ami tudományosan ugyan nem bizonyított, de hipotézis szintjén követi Mózes könyveinek 5 részre való felosztását: 1 - 41., 42 - 72., 73 - 89., 90 - 106., 107 - 150. Aztán közismertek az ún. Hallél (halleluja) zsoltárok (113 - 118.), vagy az a hét zsoltár, melyet a lévita papok recitáltak, énekeltek egy meghatározott rend alapján. ${ }^{5}$ Egy következő csoportban találjuk a 15 lépcsőzsoltárt, a Grádicsok énekeit: 120 - 134. ${ }^{6}$ Visszatérő motívumként jelenik meg két zsoltárcsoportban (42 - 83., 93 - 99.) a kijelentés: „Uralkodik az Úr.“ Ezeket Elohista zsoltároknak nevezzük. Az elnevezés onnan ered, hogy ezekben a zsoltárokban nem Jahve, hanem Elohim szerepel.

A zsoltárok további csoportosítására az egyes és többes szám is okot adhat, mert vannak egyéniek és általánosak, az egyes számban használatosak személyesek, a többes számban íródottak általános jelleget öltenek. A zsoltáros müfajt (leginkább tartalmi megközelítésből) 10 csoportba sorolhatjuk: nemzeti panaszénekek (pl. a Templom lerombolása), egyéni panaszénekek (pl. 38., az ego csak ebben a formában jelenik meg ebben az időben), nemzeti hálaének, egyéni hálaének, dicsőító ének (himnusz), liturgikus zsoltárok (pl. 92., 93), Sion-énekek (120 - 134.), király-zsoltárok (pl. 2.), Isten királyságáról szóló ének (pl. a 19.), bölcsességzsoltárok, vagy tanító zsoltárok (pl. 1.)

Azonban azt is meg kell említenünk, hogy a zsoltár előfordulása nem szükíthető le a Zsoltárok könyvére, hiszen a zsoltár mint müfaj az egész Ószövetségi kánonon végighúzódik. Ilyen példának okáért Mózes éneke (2 Móz 15:1-18):

\section{„Éneklek az ÚRnak, mert fenséges, ő lovat Lovasával tengerbe vetett. \\ Erösségem az ÚR és énekem, \\ Szabadításom lön nekem, ez az én Istenem..."}

Mirjam énekében (2 Móz 15:20-27): Mirjam prófétaasszony dobot kap elő, táncot lejtve énekelnek a nők. A bánat hangját üti meg Dávid siratóéneke (2 Sám 1:17-27), a hála hangjai szólalnak meg

4 A Septuagintában még egy, az ún. 151. zsoltár is megtalálható, melynek héber eredetijét Qumránban találták meg, míg a szír bibliában 155 zsoltárt olvashatunk. Az Újszövetség imlicit vagy explicit módon 104 zsoltárverset idéz, melyek Jézus Krisztus személyéről tesznek prófétai kijelentést. Már Jézus idejében a Zsoltárok könyve volt a legolvasottab könyv. Megjegyzésként: A Septuaginta Zsoltáros könyvét hozzávetőlegesen i. e. 3 században kezdték fordítani. A fordítás szó szerinti, szolgai jellegü és a kereszténység első zsoltárfordításai Észak-Afrikában jelentek meg i. u. a 2. században. Első szövegjavításokat Sz. Ágoston eszközöl. Európai vonatkozásban érdekes megemlíteni az itáliai Psalterium Romanumot, Hispániában a Psalterium Mozarabicumot (Szécsi 2010).

5 Tudvalevő, hogy meghatározott zsoltárokot imádkozott a zsidóság a hét minden napján (az ünnepektől itt eltekintek). Az első napon a 24. vagy a 23. zsoltárt, a másodikon a 48., a harmadikon a 82., a negyediken a 94.-et, az ötödiken a 81.-et, a hatodikon a 93. és a hetediken a 92. zsoltárt. Egy érdekes adoma kering mindmáig a prágai zsidóság körében. Golem történetéhez kapcsolódik. Szombatnap beköszönte előtt Maharal rabbi „deaktiválta“ Golemet, vagyis a fejéből kivette a golyót. Egy alkalommal elfelejtette kivenni. A szolgák futottak jelenteni a zsinagógába, ahol már a 92. zsoltárt énekelte. Mikor megtudta, hogy mi történt, kifutott, deaktiválta Golemet, visszatért, de tudatában volt, hogy megszegte a munkára vonatkozó előírásokat, hiszen 39 munkavégzés tiltott volt szombaton. Ezért újból nekifogott a 92. zsoltárnak. A mai napig ennek emlékére a prágai Altneuschul zsinagógában kétszer éneklik a 92. zsoltárt szombatnapon.

6 A 119. zsoltár után elindultak a Templomba (a zsidóság a három zarándok ünnepen felment a Templomba). Lépcsőnként megálltak a léviták, készülve szellemben, hogy belépjenek az Igazság Kapuján, ami annyit jelent, hogy Istennel találkozni. 
Anna énekében (1 Sám 2:1), zsoltáros müfajnak tekinthető Habakuk próféta imádsága is (Hab3), de ugyanilyen költészeti müremek Mózes gyönyörü búcsúéneke, mely az egész nép sorsának vázlatát adja (5 Móz 32:1-43).

A zsoltároknak a jeruzsálemi templomban elmondott vagy énekelt imákat szokás tekinteni, vagyis a Zsoltárok könyve énekesgyüjtemény, pontosabban: zenekísérettel előadott, Jahvét dicsőítő ének. Dávid király több mint hetven zsoltár szerzője a könyvben: „Egy hárfa függött Dávid ágya fölött. Amikor eljött az éjfél, az északi szél játszott rajta, és megszólaltatta akkordjait. Dávid azonnal felkelt és a Tórával foglalkozott." (Ekkor dicséreteket, dalokat jelentett). ${ }^{7}$ A zsoltár inspirálta, melyet a zenekíséret segített kiteljesedni. ${ }^{8}$ Ha megnézzük a zsoltárok verselését, szembeötlik a héber vers sajátossága, a gondolatritmus. Valamennyi keleti nép költészetére ez jellemző, de a gondolatritmus alkalmazása a tetőfokát mégis a héber költészetben érte el, ami egyrészt a szemita gondolkodás természetéböl fakad, t.i. a gondolatokat koncentrikus formában igyekszenek kifejteni, másrészt a héber versben található gondolatritmus a sémi-hámi mentalitás dinamikus és hullámzó érzelemvilágának megfelelő kifejezési formát kölcsönöz. Az egymással szembeállított gondolatok általában kétsorosak, de lehetnek hosszabbak is. Egy biztos: két gondolatot állít szembe egymással. Mind a héber, mind a bibliai szövegek gyakori rendezőelve a gondolatritmus, így a költészet belső lüktetését is a gondolatritmus adja (parallelizmus membrorum). A verssor két tagja ugyanazt a gondolatot variálja. Négy fajtája van, habár Arany János hármat említ. ${ }^{9}$ Az egyes típusokat nézzük meg konkrét példákon.

1. A rokon értelmü gondolatritmus (szinonim parallelizmus). A két gondolat csaknem egyforma, vagyis ugyanazt a gondolatot szinonim szavakkal variálja. A 2. (királyzsoltár) vagy a 114. zsoltár szinonim paralellizmusa szembeötlő (A Zsoltárok könyvén felül másutt is van rá példa a Bibliában: Péld 17:4; Ézs 9:5)

Szaggassuk le az ö bilincseiket, és dobjuk le magunkról köteleiket. (Zsolt. 2:1 - 3)

Hegyek, hogy szöktök vala, mint a

kosok? Ti halmok, mint a juhoknak bárányai? (Zsolt. 114:6)

2. Ellentétes gondolatritmus (antithetikus paralellizmus). A vers két tagja ugyanazt a mondanivalót fejezi ki, mint például a Péld 17:6-ban is, de ellentétes oldalról világítja meg az üzenetet, vagyis van egy állítás és egy tagadás, ami egymással párhuzamban van.

Azok meghanyatlanak és elesnek,

Mi pedig felkelünk és megállunk. (Zsolt. 20:9)

7 A Zsoltárok könyvét Dávidról nevezték el (2Sám 23:1), de 10 személy neve is feltűnik: Ádám, Melchizedek, Ábrahám, Mózes, Héman (egy neves bölcs, lsd: 1Kir6:18, 25, Zsolt: 88:1), Jedutun (Dávid egyik énekese), Ászáf (a babiloni fogság utáni énekescsoport ősatyja) és Kórach három fiának művei.

$8 \mathrm{Az}$ ókori ember verseléséhez eleve hozzátartozott a zenekíséret is. A psalterion nem csupán énekgyüjteményt jelent, hanem húros hangszert is, ami leginkább a lanthoz hasonló. Az éneklö ezzel kísérte önmagát.

9 Agondolatrimustartalmi-formai szempontbólösszehangoltés arányosan tagoltrokonvagyellentétesértelmű gondolatok egymásutánja. A ritmus az ún. külső, a gondolatritmus pedig a belső forma megnyilvánulása; ha ez a megformáltság tartalmi-szerkezeti jellegű, arányosságról beszélünk. A gondolatritmus ősrégi és általánosan ismert költői-stilisztikai eszköz. A magyar népköltészetben a gondolatritmus legszebb példáit a népballadákban találjuk. Arany János a Bibliában is tükröződő gondolatritmusnak három fajtáját különbözteti meg: párhuzamos, ellentétes és összerakó (Gáldi 1987, 124 - 125). 
Magdaléna Hrbácsek

Mert tudja az Úr az igazak útját,

A gonoszok útja pedig elvész. (Zsolt. 1:6)

3. A kiegészitö párhuzamban (szintetikus paralellizmus) egyik gondolat kiegészíti (szintetizálja) a másikat, mint ahogy az 1Móz 49:14-ben is olvashatunk erre példát.

Isten igaz biró, és olyan Isten, aki min-

dennap haragszik. (Zsolt. 7:12)

Én kentem ám fel az én királyomat a

Sionon, az én szent hegyemen! (Zsolt. 2:6)

4. Ismétlö párhuzam (klimatikus parallelizmus): Az ismétlés jellemző a héber közgondolkodásra. A kulcsszót vagy -szavakat egy másik szempontból világítják meg. A zsoltárokban nagyon ritkán fordul elő ez a fajtája a gondolatritmusnak, sokan nem is tartják külön kategóriának.

Adjatok az Úrnak, ti fejedelmek-

nek fiai, adjatok az Úrnak tiszteletet és

dicséretet! (Zsolt. 29:1)

Uralkodik az Úr, méltóságot öl-

tözött fel, felöltözött az Úr. (Zsolt. 93:1)

A paralellizmus mindmáig a héber vers sajátossága maradt, amit igazol A szomjúság járványa c. magyar-héber nyelvü kortárs antológia is. Nézzünk meg Haim Gouri ${ }^{10}$ és Almog Behar ${ }^{11}$ verseiből egy-egy sztichoszt (kola/vers), ahol szintetikus paralellizmussal találkozhatunk:

És ismét, mint mindig Izrael földjén, felizzanak a kövek.

és a föld nem kinál fedezéket,

és újra hívnak testvéreim a mélységből! (Haim Gouri: Számadás)

Jeruzsálemben nincsen folyó

És a folyót nem táplálják patakok,

És a patakokat nem kísérik bujazöld partok... (Almog Behar: Jeruzsálemben nincsen folyó)

A fent említett antológia előszavában olyan igazság húzódik meg, mely a bibliai költészetre is jellemző: „A költészet a lélek szomját is olthatja..." (Uri - Marno 2016, 11). Egyetemes igazság ez, ami az egyén szubjektív lelkivilágát, érzelmeit, attitűdjeit tükrözteti. Erre a legmegfelelőbb eszközök egyike a vers. Ilyenek a zsoltárok is. Az érzelmek tükröztetésén és ütköztetésén felül a héber irodalomban, mind a világiban, mind a bibliaiban, az értelem, a logikus érvelés és következtetés is központi kategória. A bölcsességirodalomban található premisszák és konklúziók szövegvilágából

10 Haim Gouri Tel Avivban született, 1947-ben Magyarországon, és Csehszlovákiában a holokauszt túlélők között tevékenykedett. Irodalmi tevékenysége mellett újságíróskodott is. Irodalmi munkásságát több díjjal ismerték el: Bialik-díj, Izrael Díj, Miniszterelnök Díj.

11 Jeruzsálemben élő író, akinek eddig két verseskötete, egy regénye és egy novelláskötete jelent meg, 2009ben Miniszterelnöki díjban részesült. 
ablak nyílik egy nemzet gondolatvilágába, ezzel gazdagítva, feszegetve saját gondolati struktúránk és világunk határait is, miközben módunkban áll megérteni, milyen múltbéli ismeretanyagból, hagyományból, kollektív és kommunikatív tudatvilágból táplálkozik a nép, mely az adott kultúrát élteti. Az „Izraelben felizzó kövek földjén, a folyó nélküli Jeruzsálemben“ máig ott lüktet az az élő tudás, melynek a nép ajkán már akkor kánonként élő szövegeit közel 3500 évvel ezelőtt kezdte az írás népe lejegyezni. Az addig a nép ajkán élö bölcsességeket, köztük a zsoltárok sokaságát is olyan célzattal írták, rendszerezték, hogy a kulturális átörökítés folyamatában megelevenedjen a primer üzenet arról, hogyan kell helyesen élni, mit ajánlott és mit tilos tenni, hogy a többi bölcsességirodalmi szöveggel amolyan mérőzsinór lehessen Izrael népén felül más népek és nemzetek számára is.

Befejezésül a fentebb részletesen tárgyalt paralellizmusokon és a bölcsességirodalom érvelési technikáinak segítségével jussunk el az 1. zsoltár üzenetéhez:

1. Boldog ember az, aki nem jár

gonoszok tanácsán, bünösök útján

meg nem áll, és

csúfolódók székében nem ül.

$\downarrow$

2. Hanem az ÚR törvényében van

gyönyörüsége, és az ő törvényeiröl

gondolkodik éjjel és nappal.

$\downarrow$

3. És olyan lesz, minta a folyóvizek mellé

ültetett fa, amely idejekorán megadja

gyümölcsét, és levele nem hervad el,

és minden munkájában jó szerencsés lészen.

$\uparrow$

4. Nem úgy a gonoszok, hanem mint a polyva,

amit szétszór a szél.

$\uparrow$

5. Azért nem állhatnak meg a gonoszok

az itéletben, sem a bünösök az igazak

gyülekezetében.

6. Mert tudja az Úr az igazak útját,

a gonoszok útja pedig elvész.

Néhány, szinte didaktikus hangvételü zsoltárban és a bölcsességirodalomban általában három elem van jelen: a mondás (ami példát, tanítást rejt magában), tiltás és parancs. Aki az ókorban rendelkezett ilyen tudással és eszerint próbált élni, az bölcs volt. Azonban az ókori bölcsesség vagy a bölcs ember fogalmának jelentése eltér a szó mai fogalmi körétöl. Az ókori bölcs olyan ember volt, aki istenfélő és gyakorlatias is egyben, tehát két lábbal jár a földön, de tudja, hogyan kell Istent követni. A 6 sztichoszból álló 1. zsoltár is bölcsességzsoltár, tanítózsoltár, mintegy útmutatás, intelem. Ki a boldog ember? - kérdezi a vers szerzője a zsoltárt felvezető sorban, amire az 1. és a 2 vers didaktikus hangot megütő premisszáival válaszol, sőt, kijelentésről kijelentésre fokozza is ezt, felhasználva a szintetikus paralellizmus eszközét és konkrét eseteket, attitüdöket (bünösök útján meg nem áll, csúfolódók székébe nem ül) ír le bölcsességként, a zsoltár másik felében pedig ostobaságként. A kulcsmondat, az üzenet a vers közepén van elrejtve, a 3. versben, 
majd a 3. és 4. sztichoszok bináris oppozíciókat (igaz-hamis, jó-rossz, okos-balga) metaforikus képekben tárnak elénk: a helyes úton járók élete olyan gyümölcsöző lesz, mint a folyóvizek mellé ültetett fa. A megfigyelő jellegü (folyóvizek mellé ültetett fa) kép a gyümölcsöző életet jelképezi, míg a polyva a tartalmatlanság, gonoszság, a haszontalan és értelmetlen dolgok képe. Ez a kép megerősíti az embert abban, hogy élő vizek forrásánál, a folyónál: Isten igéjénél kell letelepednie annak, aki boldog akar lenni, ellenben a költői hasonlattal élve olyan lesz, mint a polyva, melyet elfúj a szél. Ez a zsoltár nem tilt és nem parancsol, ellenben cizelláltan tanácsol. A 4. és az 5. vers az 1. és a 2. vers ellentétében feszíti a verskeretet, vagyis míg az 1. és 2. vers bemutatja, hogyan kellene járni bölcsességben, addig a 4. és 5. amellett érvel, hogyan nem. A konklúziót a záró sztichosz adja a maga ellentétes paralellizmusával. A bölcsesség és butaság/balgaság gyakorlati értelemben vett tulajdonságok, ahol mindkét fogalom lényegében az igazsággal és a gonoszsággal egyező értelemben használatos. A bölcsek viselkedése és tettei a jólétben gyümölcsöznek, míg a balgaság szerencsétlenséget hoz a balgák fejére. A jó cselekedetnek jó, a rossznak rossz gyümölcse lesz, melynek az emberi prizmán keresztül szemlélt ok-okozati szigorát és látható, sokszor tapasztalható következményét felülírja/felülírhatja Isten kegyelme azoknál, akik megtérnek a „rossz“ útról, és/ vagy bűnbánatot tartanak. Míg ide eljut az ember, addig jó, ha tudjuk, a zsoltároknak mindig ideje van, megtanítanak fohászkodni, és ahogy Náhmán rabbi tanácsolja:

Földi életünkben, Istenhez való ragaszkodásunk legközvetlenebb kifejezése a zene és a dal. Kezdj dalba akkor is, ha nem énekelsz szépen. Dalolj magadnak, mikor egyedül vagy a házadban. A lényeg, hogy énekelj. ${ }^{12}$

Éppen úgy, ahogy a 150. zsoltárban írva van: Dícsérjétek az Urat!

\section{Summary}

The psalms are part of Hebrew and Christian canons. The poems in the Book of Psalms are masterpieces of biblical poetry, which are mentioned as a belonging of wisdom literature. I examined the poems from two point of views: I try to show the peculiarity of Hebrew poem, the occurrence and types of thought rythm (synonymous, antithetic, synthetic and climatic paralelism) then I compare it with a modern Hebrew poem and I ascertain that the Hebrew poems contain the thought rythm up to now. Because the Book of Psalms belongs to the wisdom literature, I monitored the three typical elements of genre, which are the example, ban and command and reasoning techniques. I prove it by detailed analysis of the 1. Psalm, where we can find permissions and conclusions as well.

\section{IRODALOM}

Fröchlich, Ida, 2005. A qumráni szövegek magyarul. Budapest: PPBTK.

Gáldi, László, 1987. Ismerjük meg a versformákat! Bratislava: Madách Kiadó.

Prince, Derek, 2012. A Szellem ajándékai. Budapest: PATMOS Könyvek

Szécsi, József, 2010. A zsoltárok megjelenése a görög-latin fordításokban, valamint a Talmudban és a Midrásban. Budapest: ORZSE, [online letöltve: 2019. 5. 15.] http://www.or-zse.hu/hirdetes/ zsoltarkonf2010/szecsi-zsoltar-2010.htm.

Szent Biblia, 2012. Budapest: Patmos records (Károli Gáspár fordítása alapján).

Szerdahelyi, István, 1997. Müfajelmélet mindenkinek. Budapest: Akadémiai Kiadó.

Uri, Asaf - Marno, János, 2016. A szomjúság járványa. Budapest: Kalligram.

12 Náhmán rabbi, a nagy misztikus gondolkodó a 18. században élt, Breslavból származott. Nátán rabbi tanítványa volt (Uri - Marno 2016, 98). 


\section{ELÉRHETŐSÉG}

PaedDr. Hrbácsek Magdaléna, PhD.

Ústav stredoeurópskych jazykov a kultúr ÚKF FSŠ

Dražovská 4

94974 Nitra

Slovenská republika

mhrbacek@ukf.sk 